Article

\title{
Interaction Mechanism between Molybdenite and Kaolinite in Gypsum Solution Using Kerosene as the Flotation Collector
}

\author{
Liqing Sun ${ }^{1}$, Yijun Cao ${ }^{2,3, *}$, Yinfei Liao ${ }^{2}$ and Zilong $\mathrm{Ma}^{2}$ \\ 1 School of Chemical Engineering and Technology, China University of Mining and Technology, \\ Xuzhou 221116, China; slqcumt@cumt.edu.cn \\ 2 National Engineering Research Center of Coal Preparation and Purification, \\ China University of Mining and Technology, Xuzhou 221116, China; liaoyinfei@cumt.edu.cn (Y.L.); \\ mazl@cumt.edu.cn (Z.M.) \\ 3 Henan Province Industrial Technology Research Institution of Resources and Materials, \\ Zhengzhou University, Zhengzhou 450066, China \\ * Correspondence: caoyj@cumt.edu.cn; Tel.: +86-0516-8359-1116
}

Received: 31 May 2018; Accepted: 18 July 2018; Published: 20 July 2018

\begin{abstract}
This paper aims to understand the fundamental interaction mechanism between molybdenite and kaolinite in gypsum solution using kerosene as collector. Micro-flotation tests were conducted to study the effect of gypsum solution on the flotation performance of mixed $-74 \mu \mathrm{m}$ molybdenite and $-10 \mu \mathrm{m}$ kaolinite mineral. The results showed that the recovery of molybdenite decreased from $86 \%$ to $74 \%$ while the gypsum solution concentration increased from 0 to $800 \mathrm{mg} / \mathrm{L}$, indicating the detrimental effect of kaolinite on molybdenite flotation could be enhanced by gypsum solution. This is mainly caused by the slime coating of kaolinite on molybdenite through dissolved calcium ion of gypsum solution. In order to confirm the slime coating phenomenon, zeta potential distribution, scanning electron microscopy (SEM) and atomic force microscopy (AFM) measurements were used to investigate interaction characteristics and mechanisms. The zeta potential distribution results revealed that mixed samples had the value between signal molybdenite and kaolinite samples in gypsum solution, which proved the coating phenomenon of kaolinite on molybdenite. Moreover, the coating phenomenon was becoming more and more obvious with the gypsum solution concentration. The coating phenomenon of kaolinite on molybdenite surface was also directly observed from SEM results. The AFM results provided further evidence for the possibility of slime coating, as the adhesion force increased with the gypsum solution concentration, which means the aggregates of molybdenite and kaolinite were becoming more stable.
\end{abstract}

Keywords: molybdenite flotation; kaolinite; gypsum solution; interaction mechanism; atomic force microscope

\section{Introduction}

Molybdenite $\left(\mathrm{MoS}_{2}\right)$ is a valuable sulfide mineral with inherent floatability. It is mainly used as the lubricant [1], catalyst [2,3], pigment in chemical industry, and recently has been applied in nanoelectronics and optoelectronics $[4,5]$. The crystal of molybdenite is determined as a layer structure, so it can generate two different cleavage surfaces named face and edge. According to the literature, the face plane shows better hydrophobicity than the edge [6]. As the average particle size decreases, the ratio of face to edge decreases, which causes the natural floatability of molybdenite to become bad with the decrease of particle size [7]. More than that, molybdenite recovery can be also affected by $\mathrm{pH}$, 
ion in process water and clay minerals etc. [8-10]. Researchers have demonstrated that contact angle of molybdenite decreases slightly as $\mathrm{pH}$ increases [11].

Kaolinite is a typical clay mineral, which exists in flotation system as colloidal particles with an average size of about $500 \mathrm{~nm}$, according to Gupta and Miller's work [12]. Nanoparticles can worsen objective mineral flotation performance by increasing the slurry viscosity, promoting slime coating and entrainment phenomena [13-16]. Hence, the study on improving flotation recovery and utilization of objective minerals from kaolinite has attracted more interest from researchers [17,18]. However, the interaction between kaolinite and molybdenite has not got enough attention from researchers maybe because the surface potential of kaolinite and molybdenite are similar in sign and repel each other. Many present studies just show that the poor molybdenite floatability can be caused by adhesion of non-sulfide gangue to the molybdenite surface [19]. So, the study on the interaction mechanism between kaolinite and molybdenite is a realistic problem demanding studying and solving urgently.

It was reported that water quality can depress the molybdenite flotation, especially the calcium ion in process water. Among the multiple sources of calcium ion, the dissolution of calcium-bearing minerals is a primary one. Gypsum is often present in ores and associates with clay minerals, which can generate calcium ion and sulfate ion [20]. The inhibition of calcium ion on molybdenite flotation has been confirmed by many scholars. The scholars indicate that the floatability of molybdenite is reduced at $\mathrm{pH}$ above 9, and the depressing effect is proportional to calcium ion concentration [21]. In acid media, except physical adsorption, the calcium ion is suggested to adsorb onto the edge face through forming a surface coating of $\mathrm{CaMoO}_{4}$. The flotation depression might be attributed to the competition among compression of the double layer and the chemical adsorption [10]. In previous studies, analytically pure calcium chloride was used as a source for calcium ion to study its effect on molybdenum flotation [21,22]. Moreover, scholars have further studied the effect of sulfate ion on sulfide mineral (galena) flotation, which indicated that it has some depressing effect on flotation by competing with collector molecule adsorption on the mineral surface, which was different with chloride ions [23]. So, in this paper, gypsum solution was prepared in the lab to use as process water.

Colloidal particle interaction plays a key role in the flotation process, which determines the stability of particles. Therefore, a better understanding of the interaction between objective minerals and clays can give a significant guiding for improving objective minerals recovery in practice. Many classical methods are developed to study colloidal particle interactions. The zeta potential distribution has been used to characterize the colloidal particle stability, which provides a favorable proof for slime coating in colloidal system [24-26]. With the wide application of atomic force microscopy (AFM) in mineral processing, it provides a new insight into understanding the physicochemical properties (e.g., surface roughness, surface potential) of mineral surface and the fundamental interaction mechanism between particles [27,28]. The silicon nitride AFM tips are most commonly used in the measurements, which should be functionalized to perform close to the actual particle properties. This idea of attaching a microsphere at end of the AFM tip was introduced by Ducker et al. [29], which was used for force-distance measurements between individual colloid particle and a planar surface. Since then, AFM has been successfully used to determine the magnitude of the interaction forces between colloidal particle and surface [30,31]. However, the interaction forces between kaolinite particle and molybdenite surface has not been measured yet.

The aim of this study is to investigate the role of gypsum solution on the interaction of kaolinite and molybdenite. Interaction characteristics and mechanisms are better descried using SEM measurements, zeta potential distribution and AFM. 


\section{Materials and Methods}

\subsection{Materials}

Molybdenite used in this study was obtained from Guangxi Province, China. It was hand-picked, crushed and ground by porcelain mill and sieved to obtain $-74 \mu \mathrm{m}$ for tests. Both of X-ray diffraction spectrums (XRD) and X-ray Fluorescence (XRF) were used to examine the purity of molybdenite. The results of XRD and XRF are shown in Figure 1 and Table 1, respectively. The XRD result shows that the main peaks match the standard molybdenite peaks perfectly, and there are almost no impure peaks. The chemical contents result shows that there are about $55.19 \%$ molybdenum in sample, which illustrate the purity of molybdenite is $92 \%$.

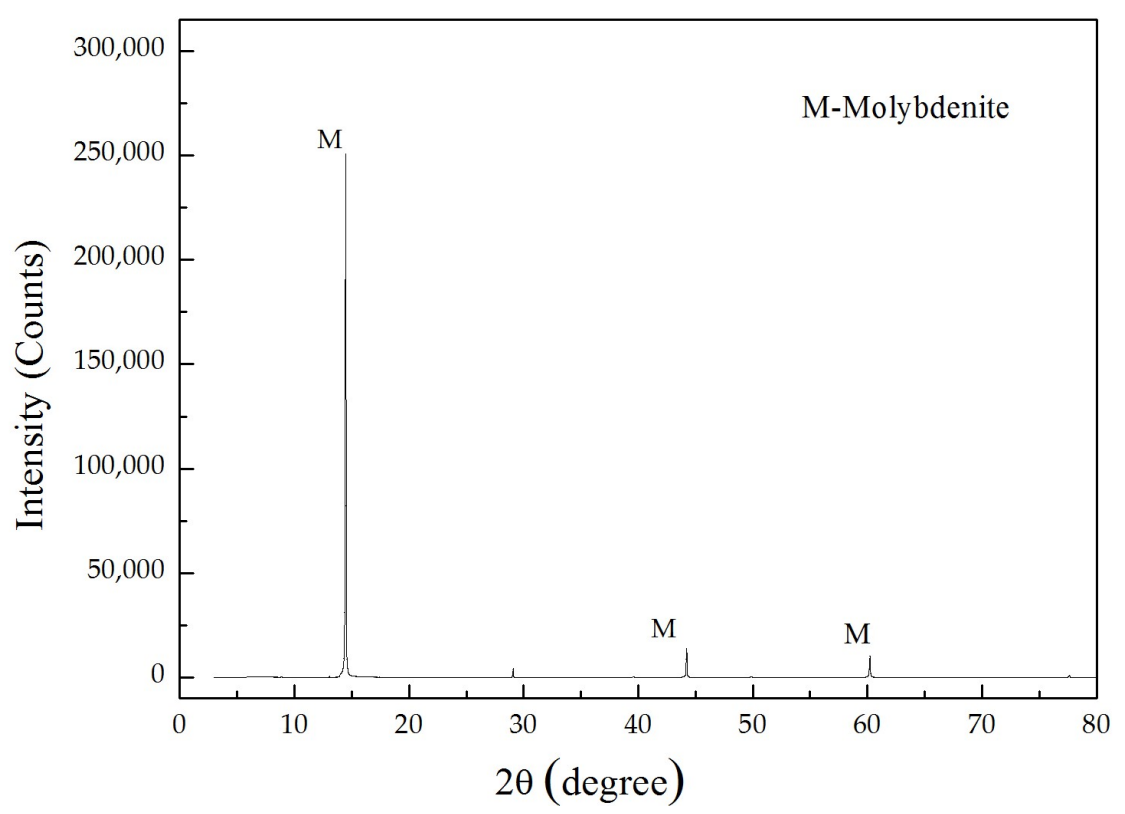

Figure 1. X-ray diffraction spectrum of pure molybdenite.

Table 1. Chemical contents of the pure molybdenite and kaolinite samples.

\begin{tabular}{ccccccc}
\hline Chemical Composition & $\mathbf{S}$ & $\mathrm{Mo}$ & $\mathrm{SiO}_{2}$ & $\mathrm{Al}_{2} \mathrm{O}_{3}$ & $\mathrm{Fe}$ & Others \\
Molybdenite & 41.27 & 55.19 & 2.25 & 0.55 & 0.46 & 0.28 \\
\hline Chemical Composition & $\mathrm{Al}_{2} \mathrm{O}_{3}$ & $\mathrm{SiO}_{2}$ & $\mathrm{TiO}_{2}$ & $\mathrm{Na}_{2} \mathbf{O}$ & Others & LOI \\
Kaolinite & 39.77 & 47.51 & 0.68 & 1.02 & 0.74 & 10.28 \\
\hline
\end{tabular}

The kaolinite powder was obtained from Hebei Province, China. The $-10 \mu \mathrm{m}$ kaolinite was prepared in the laboratory using siphon principle, which was fit well with the kaolinite size in flotation. The siphon experiment was conducted in a 2 L beaker based on the following equation:

$$
u_{t}=\frac{\Delta \rho g d^{2}}{18 \mu}
$$

where, $u_{t}$ is settling velocity in the uniform settling stage; $\Delta \rho$ is the density difference between kaolinite and water, $1.63 \times 10^{3} \mathrm{~kg} / \mathrm{m}^{3} ; g$ is the gravitational acceleration, $9.8 \mathrm{~m} / \mathrm{s}^{2} ; d$ is the settling distance, $18 \mathrm{~cm} ; \mu$ is water viscosity, $1 \times 10^{-3} \mathrm{~Pa} \cdot \mathrm{s}$.

So, in order to get $-10 \mu \mathrm{m}$ kaolinite samples, the settling time should be $32 \mathrm{~min}$. The X-ray Fluorescence was also used to study the chemical contents of kaolinite. The result is shown in Table 1 , which displays that there are about $39.77 \% \mathrm{Al}_{2} \mathrm{O}_{3}$ and $47.51 \mathrm{SiO}_{2}$, so it sufficiently met the requirement 
for using in subsequent experiments. The size distribution of the molybdenite and kaolinite were measured by a laser diffraction particle size analyzer (S3500, Microtrac Inc., Largo, FL, USA), and the results are shown in Figure 2. The results indicate that mean particle size for molybdenite and kaolinite are $16 \mu \mathrm{m}$ and $2.6 \mu \mathrm{m}$, respectively. And more than $97 \%$ cumulative volume of kaolinite sample is smaller than $10 \mu \mathrm{m}$. The gypsum lump ore $\left(\mathrm{CaSO}_{4} \cdot 2 \mathrm{H}_{2} \mathrm{O}\right)$ was purchased from Guangxi Province, China. It was also crushed and ground to $-74 \mu \mathrm{m}$ and stored to prepare solution.

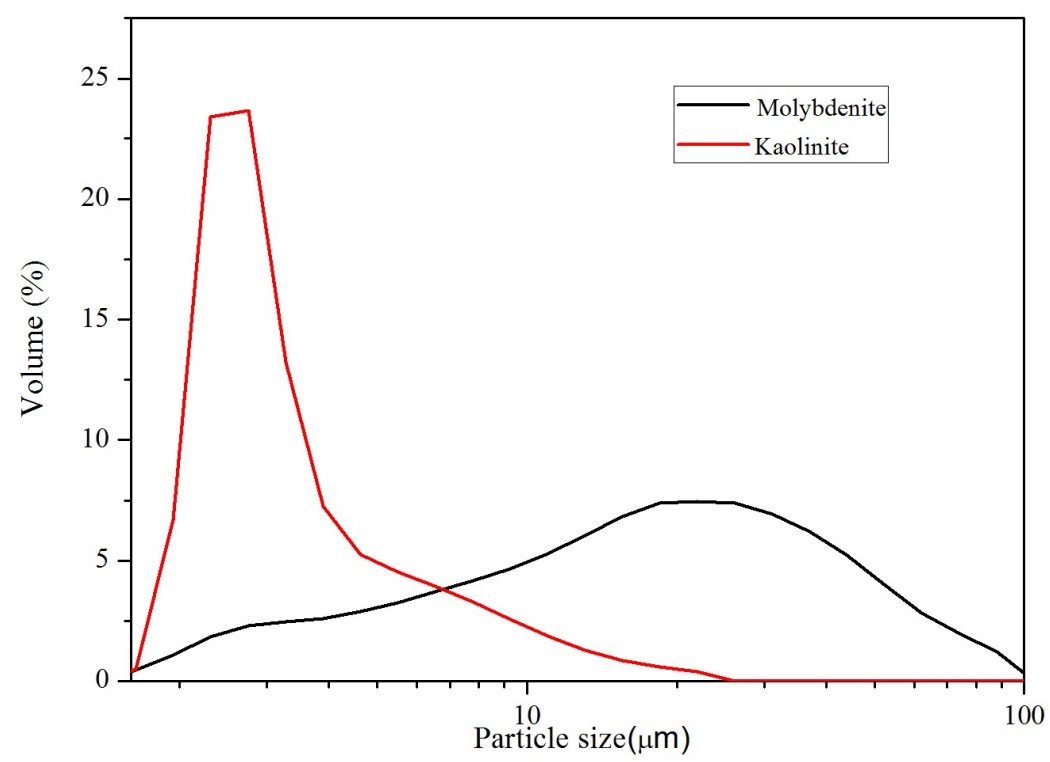

Figure 2. Particle size distribution of molybdenite and kaolinite samples.

Commercial kerosene was used as collector, and pine camphor oil was used as frother in the flotation process. They were both bought from local industry. Other reagents used in this work were all AR grade, which were bought from Aladdin Biochemical Technology Co. Ltd. (Shanghai, China). Milli-Q water was used in the whole tests. Gypsum solutions with different concentration were prepared by adding certain weight gypsum in milli-Q water and agitating on a magnetic stirrer until it's all dissolved.

\subsection{Micro-Flotation Tests}

Mineral micro-flotation tests were carried out using a mechanical XFG machine (Nanchang Jianfeng Mining Machinery Manufacturing Co., Ltd., Jiangxi, China) at a constant rate of $1600 \mathrm{r} / \mathrm{min}$ [32]. The pulp was prepared by adding $2 \mathrm{~g}$ mixed minerals to $40 \mathrm{~mL}$ gypsum solution which was prepared beforehand. Before adding the agents, the pulp was fully dispersed for $3 \mathrm{~min}$. Then collector was added and conditioned for $3 \mathrm{~min}$. Subsequently, the frother was added, and keep conditioned for $2 \mathrm{~min}$. After that, the micro-flotation was continued for $3 \mathrm{~min}$. Both of froth products and tailings were filtered, dried and weighed for molybdenum content analysis. The molybdenum content was determined by Inductively Coupled Plasma (OPTIMA8300, PerkinElmer Inc., Fremont, CA, USA). Before testing, the samples were molten by sodium peroxide and acidified by hydrochloric acid. Based on molybdenum content distributions in froth product and tailing, the molybdenite recovery was calculated as following equation:

$$
R(\%)=\frac{W_{f} \times M_{f}}{W_{f} \times M_{f}+W_{t} \times M_{t}}
$$

where $R$ is the recovery of molybdenite; $W_{f}$ is the weight of froth product; $W_{t}$ is the weight of tailing product; $M_{f}$ is the molybdenite grade in froth product; $M_{t}$ is the molybdenite grade in tail product. 


\subsection{SEM-EDS Measurements}

Repeating the micro-flotation process, the samples were conditioned in flotation machine. After conditioned, the froth product was collected by pipette and transferred to watch glass, and completely dried in the air at room temperature [18]. The dried samples were coated with a thin layer of gold and observed in high vacuum using an SEM (Quanta TM 250, FEI Ltd., Hillsboro, OR, USA). Meanwhile, their compositions were detected with an energy-dispersive X-ray spectrometer (EDS).

\subsection{Zeta Potential Distribution Measurements}

The zeta potential distribution of individual and combined samples in gypsum solutions were measured using a ZETAPALS (Brookhaven Instruments Co., Holtsville, NY, USA). The Smoluchowski model was used to calculate the zeta potential in this instrument. The individual molybdenite and kaolinite were prepared separately by adding $0.05 \mathrm{~g}$ particles to $50 \mathrm{~mL}$ pre-prepared gypsum solutions with $1 \mathrm{mM} \mathrm{KCl}$ solution, while the combined sample were prepared by adding $0.05 \mathrm{~g}$ mixed mineral (mass ratio of molybdenite and kaolinite was 1:1). All samples were conditioned for 15 min on magnetic stirrer. After settling for $40 \mathrm{~min}$, the upper particle suspensions were moved to rectangular electrophoresis cell for measurements. Each testing was repeated 5 times.

\subsection{AFM Force Measurements}

\subsubsection{Preparation of Molybdenite Surface and Kaolinite Probe}

The natural cleavage surface of molybdenite was acquired by peeling off several layers with adhesive tape [33]. The received molybdenite surface was first washed with ultrapure water and ethanol to insure the surface was clean, after that, it was dried with nitrogen. A typical AFM image of the treated surface using scanasyst-air mode imaging at a rate of $1 \mathrm{~Hz}$ is shown in Figure 3 . As shown in the figure, the surface has mean roughness of $1.07 \mathrm{~nm}$, which is suitable for colloidal force measurement using AFM. Silicon nitride tips (CSC37, ISB Ltd., Watsonville, CA, USA) were used for force measurements. A kaolinite particle with diameter about $10 \mu \mathrm{m}$ was glued onto an AFM cantilever apex using epoxy resin. The spring constant of the probe cantilever was modified on hard silicon dioxide in testing liquids.

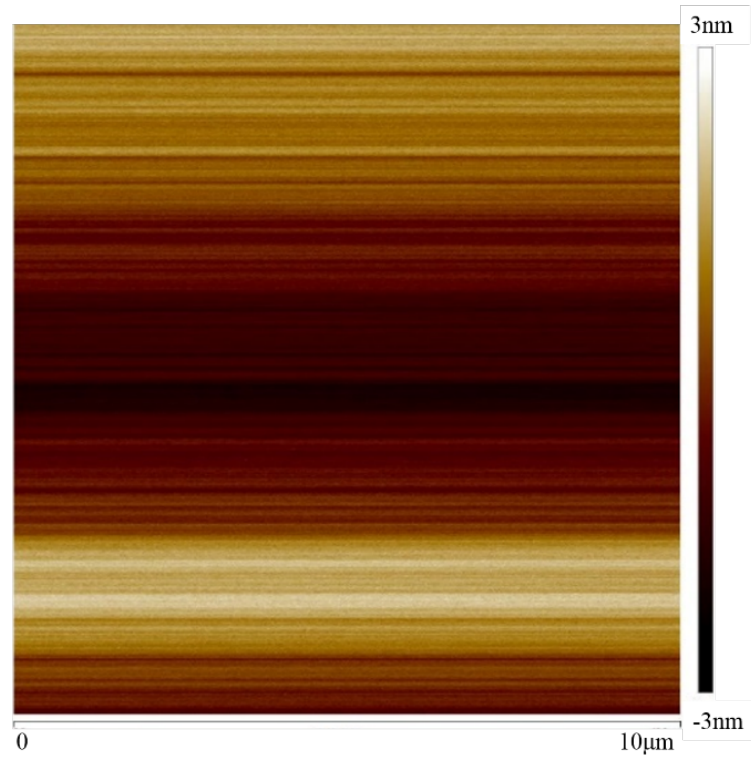

Figure 3. An AFM image of the tested molybdenite surface. 


\subsubsection{Colloidal Force Measurements}

In order to study the interaction forces between a kaolinite particle and natural cleavage surface of molybdenite, a Nanoscope Multimode 8 AFM system (Bruker, Ettlingen, Germany) was used to directly measure the forces between molybdenite and kaolinite (Figure 4a). The measurement system was generally simplified as sphere-flat system, as shown in Figure $4 \mathrm{~b}$. A laser beam is emitted to the back of the cantilever, and reflected to a split photodiode. The force between the tip and surface can cause the deflection of the cantilever, which can be detected by the split photodiode. The signal was recorded during the tests.

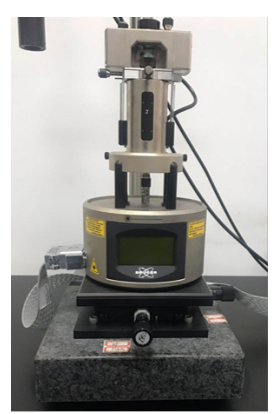

(a)

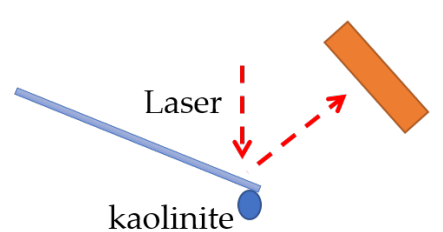

Molybdenite surface

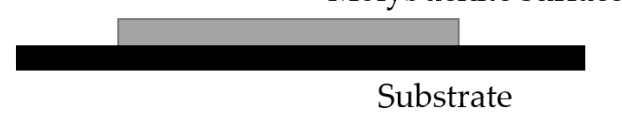

(b)

Figure 4. (a) Nanoscope Multimode 8 AFM; (b) Schematic of force measurements between molybdenite surface and kaolinite particle.

Before each test, the surface was soaked in testing liquids for $30 \mathrm{~min}$ and was glued onto a magnetic disk. The force measurements were carried out in contact mode under different gypsum concentration solutions using a liquid cell. Each measurement was taken at three locations.

\section{Results and Discussions}

\subsection{Effect of Gypsum Solution Concentration on Molybdenite Recovery}

Micro-flotation tests were conducted to inspect the effect of gypsum solution concentration on molybdenite recovery from mixed minerals. A series of gypsum solution concentration were investigated: 0 (deionized water), 200,400,600 and $800 \mathrm{mg} / \mathrm{L}$. The $\mathrm{pH}$ of deionized water is about 7, while the $\mathrm{pH}$ of gypsum solution is 6.5. Moreover, when gypsum solution concentration varies from $200 \mathrm{mg} / \mathrm{L}$ to $800 \mathrm{mg} / \mathrm{L}$, the $\mathrm{pH}$ varies less than $0.2 \mathrm{pH}$. For each test, the mass ratio of molybdenite and kaolinite is 9:1. The dosage of the kerosene and pine camphor oil is $350 \mathrm{mg} / \mathrm{L}$ and $45 \mathrm{mg} / \mathrm{L}$, respectively. Figure 5 shows the molybdenite recovery and grade in froth product as the function of gypsum solution concentration. As shown in Figure 5, the molybdenite recovery decreases with the gypsum solution concentration. The largest decline of molybdenite recovery is observed among $200 \mathrm{mg} / \mathrm{L}$ and $800 \mathrm{mg} / \mathrm{L}$ gypsum solution. The increment of gypsum solution concentration has a bit of impact on molybdenite grade, and the trend of its variations is the same as molybdenite recovery. The flotation recovery of molybdenite in deionized water is up to $86 \%$ in $\mathrm{pH}$ around 6.5 , and the molybdenite grade is up to $87.3 \%$. As the gypsum solution concentration increases to $800 \mathrm{mg} / \mathrm{L}$, the molybdenite recovery and grade decreases to $74 \%$ and $85.6 \%$, demonstrating that the gypsum solution can effectively worse molybdenite recovery from molybdenite-kaolinite mixture. 


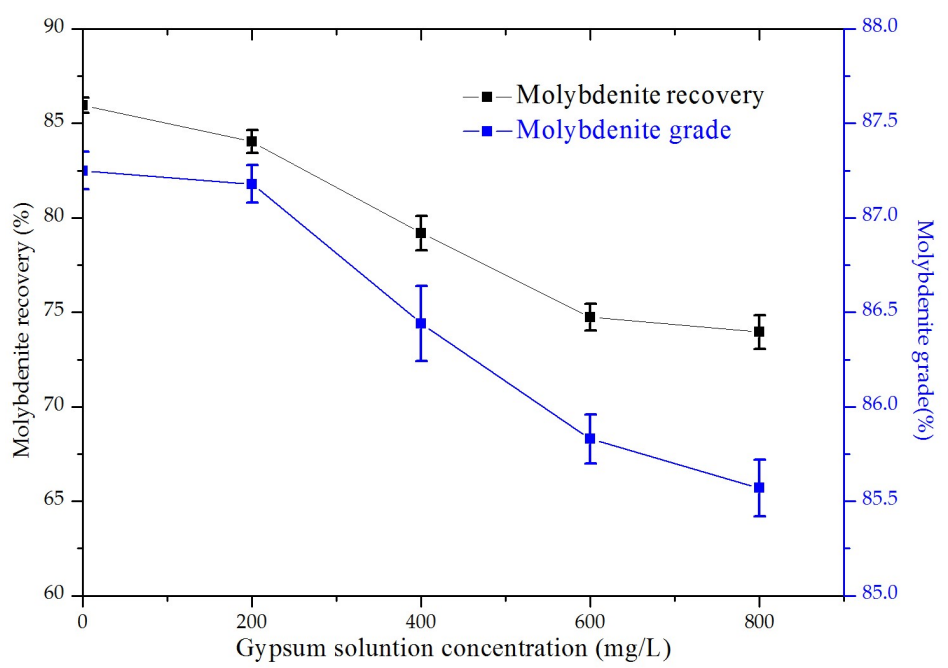

Figure 5. Molybdenite recovery and grade varied as gypsum solution concentration.

When gypsum solution increases from $200 \mathrm{mg} / \mathrm{L}$ to $800 \mathrm{mg} / \mathrm{L}$, the concentration of dissolved ion $\mathrm{Ca}^{2+}$ increases. The presence of dissolved $\mathrm{Ca}^{2+}$ ion can adsorb on molybdenite face and reduce the contact angle, which can depress molybdenite floatability [6], and this is one of the reasons why molybdenite recovery and grade in froth decrease with gypsum solution concentration. Moreover, according to the reference $[15,34,35]$, kaolinite can depress objective mineral through slime coating phenomena, so the other reason maybe is the slime coating phenomena of kaolinite on molybdenite is enhanced by $\mathrm{Ca}^{2+}$ ions.

\subsection{SEM-EDS Analysis}

In order to find out that if there is a kaolinite coating on molybdenite surfaces, SEM equipped with EDS was used to directly observe the microstructural characteristics and elemental compositions of froth product in $200 \mathrm{mg} / \mathrm{L}$ (Figure 6a) and $800 \mathrm{mg} / \mathrm{L}$ (Figure 6b) gypsum solution. From the SEM picture as shown in Figure 6a, it can be seen that a little of small particles are observed on molybdenite surface. Meanwhile, a large number of small particles are found nearly cover the surface of molybdenite surface in Figure 6b. First, analyzing from the size magnitude of the small particle, it maybe kaolinite. The EDS analysis results also show that main elements in two samples are Mo, S, $\mathrm{Al}, \mathrm{O}$, and $\mathrm{Si}$ elements. While Mo and $\mathrm{S}$ elements represent molybdenite, the $\mathrm{Al}, \mathrm{O}$, and $\mathrm{Si}$ elements are constituent elements for kaolinite. It indicates that the small particle is kaolinite. So, the coating phenomenon of kaolinite on molybdenite surface is confirmed.

\subsection{Zeta Potential Distribution Measurements}

Zeta potentials distribution method was used to characterize the surface charge property and the interaction mechanism between molybdenite and kaolinite particles, which was detailed described in the literature [24]. This method could apply to two components with totally different surface potential property. When the measured zeta potential distribution of combined sample shows two distribution peaks, indicating the two components do not attract to each other under a certain solution environment. If not, there is an attraction between the two components. 

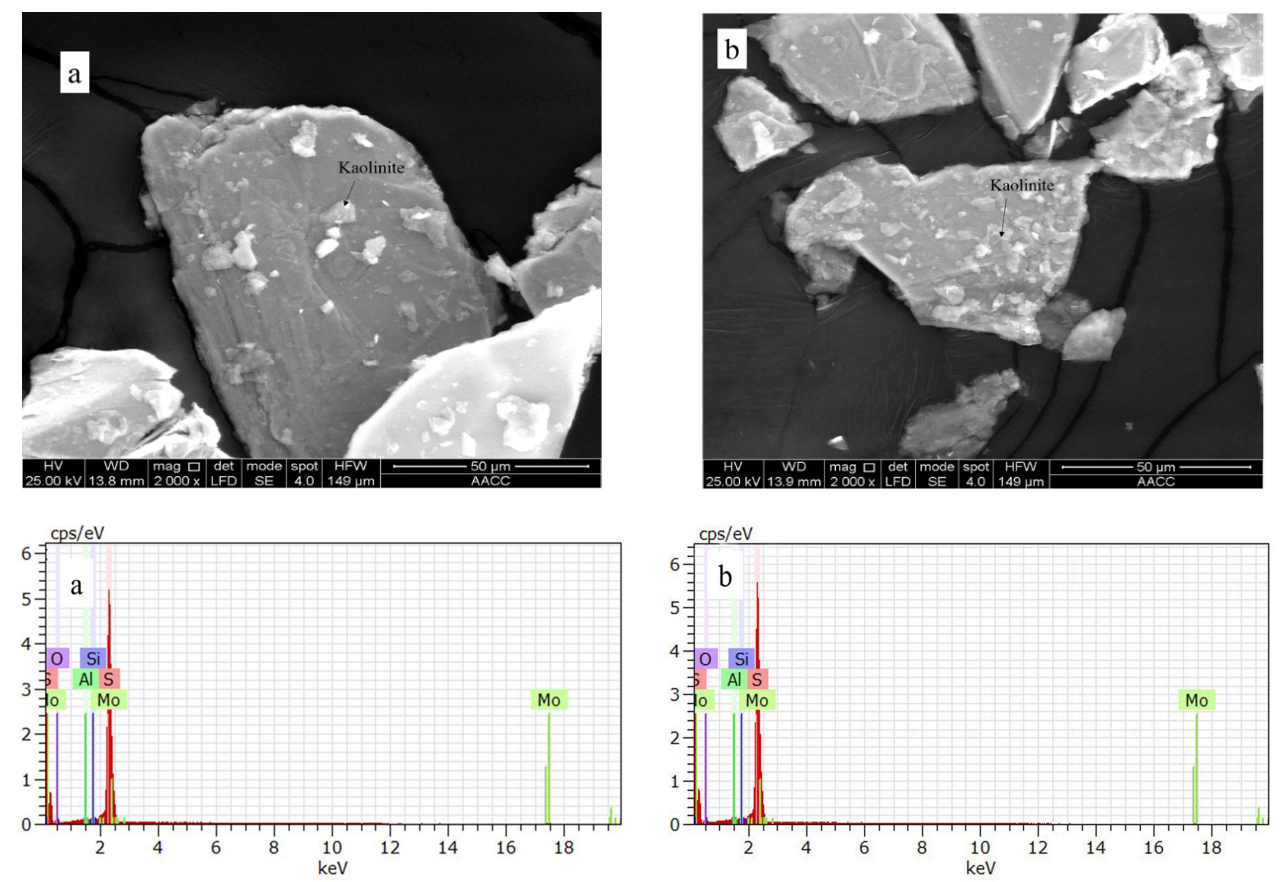

Figure 6. SEM image and EDS analysis of froth product in gypsum solution: (a) SEM image and EDS analysis of froth product in $200 \mathrm{mg} / \mathrm{L}$; (b) SEM image and EDS analysis of froth product in $800 \mathrm{mg} / \mathrm{L}$ gypsum solution.

The zeta potential distributions of individual and molybdenite-kaolinite mixture in deionized water are shown in Figure 7. The peaks of individual molybdenite sample in deionized water appear at $-21 \mathrm{mV}$, which is closer to the reference results [36]. Under this condition, kaolinite particles exhibit more negative zeta potentials than molybdenite, and the value of $-45 \mathrm{mV}$ coincides with that obtained in the literature $[37,38]$. The distribution of mixture in Figure $7 \mathrm{~b}$ is bimodal curve, and the two peaks are consistent with the peaks of the individual minerals, indicating that there is no attraction between molybdenite and kaolinite in deionized water.

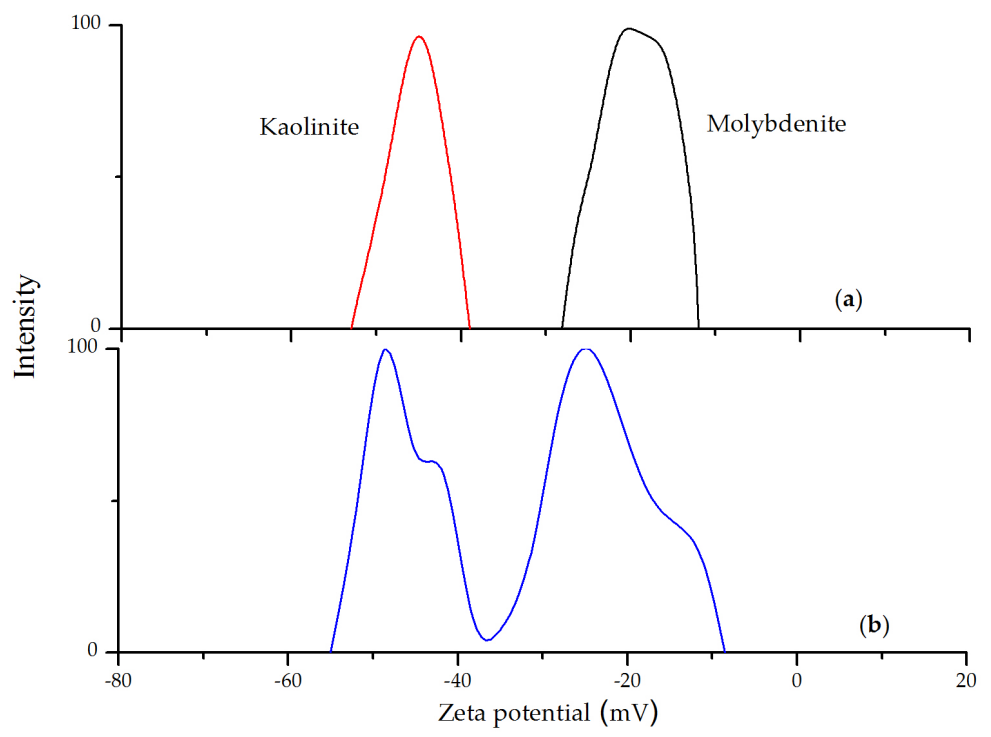

Figure 7. Zeta potential distributions in distilled water with $1 \mathrm{mM} \mathrm{KCl}$; (a) Individual; (b) Mixture. 
The zeta potential distributions of individual and molybdenite-kaolinite mixture in gypsum solution are shown in Figure 8a-d. As the concentration of gypsum solution changes from $200 \mathrm{mg} / \mathrm{L}$ to $800 \mathrm{mg} / \mathrm{L}$, the zeta potential values of individual molybdenite and individual kaolinite become less negative. The peak of individual molybdenite increase from $-18 \mathrm{mV}$ to $-10 \mathrm{mV}$, and kaolinite increase from $-37 \mathrm{mV}$ to $-20 \mathrm{mV}$, respectively. This is largely because the adsorption of free calcium ion dissolved by gypsum on mineral surface, as the raw of molybdenite and kaolinite particles are negatively charged, they can easily attract the cations to the surface. Meanwhile, the peak of molybdenite-kaolinite mixture has the value between individual kaolinite and molybdenite under the same solution environment, which indicates the coating phenomenon of kaolinite on molybdenite occurs. Even the particles of molybdenite and kaolinite carry the same sign of charge, kaolinite particles maybe coat on the molybdenite surface through an ion bridge. Moreover, when gypsum concentration increased, the peak value of molybdenite-kaolinite mixture is becoming closer to that of individual kaolinite, indicating that the slime coating phenomenon is getting more obviously. At $800 \mathrm{mg} / \mathrm{L}$, the zeta potential peak of molybdenite-kaolinite mixture is located at $-19.6 \mathrm{mV}$, which behavior much like individual kaolinite, as shown in Figure 8d.

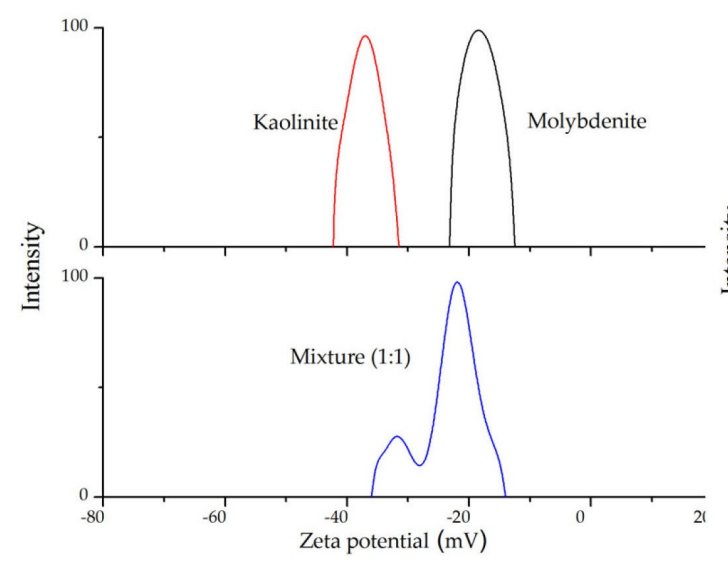

(a)

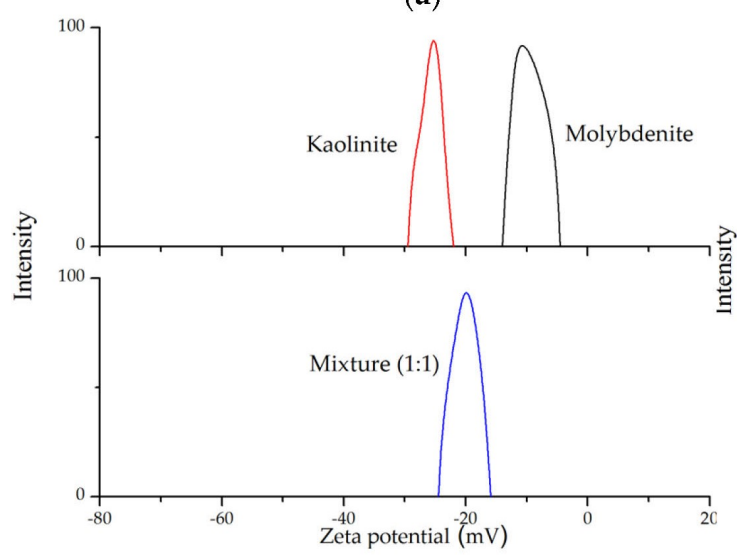

(c)

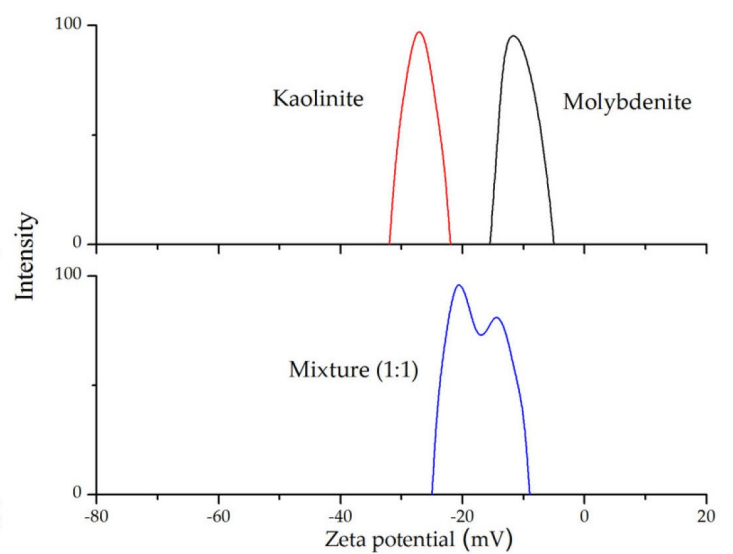

(b)

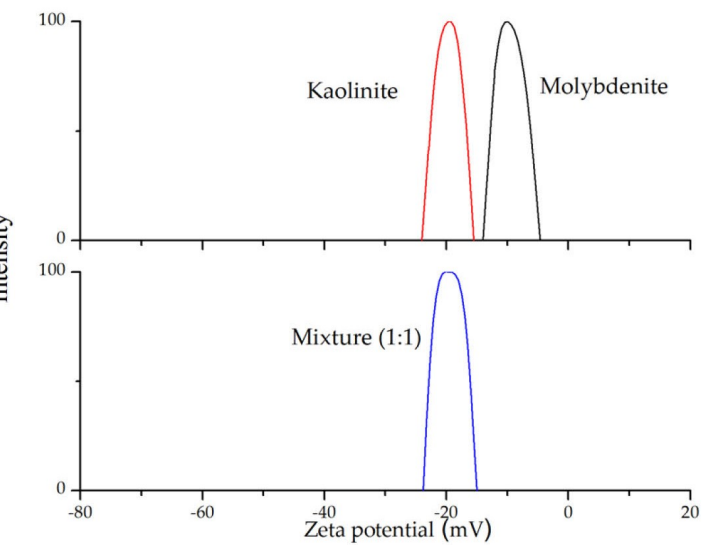

(d)

Figure 8. Zeta potential distributions of individual and mixed molybdenite-kaolinite with $1 \mathrm{mM} \mathrm{KCl}$ in (a) $200 \mathrm{mg} / \mathrm{L}$ gypsum solution; (b) $400 \mathrm{mg} / \mathrm{L}$ gypsum solution; (c) $600 \mathrm{mg} / \mathrm{L}$ gypsum solution; (d) $800 \mathrm{mg} / \mathrm{L}$ gypsum solution.

\subsection{Interaction Forces between the Kaolinite Particle and Molybdenite Face Surface}

For mixed mineral system, the attraction between desired mineral and clay is the main factor in the decline of desired mineral flotation recovery. Atomic force microscopy has been widely applied in measuring the forces between the particle-surface [39-41]. According to the SEM results in Figure 6, 
the moybdenite powder used in the paper almost exhibit face surface, so the interaction forces are only measured using molybdenite face surface. The results are shown in Figure 9.
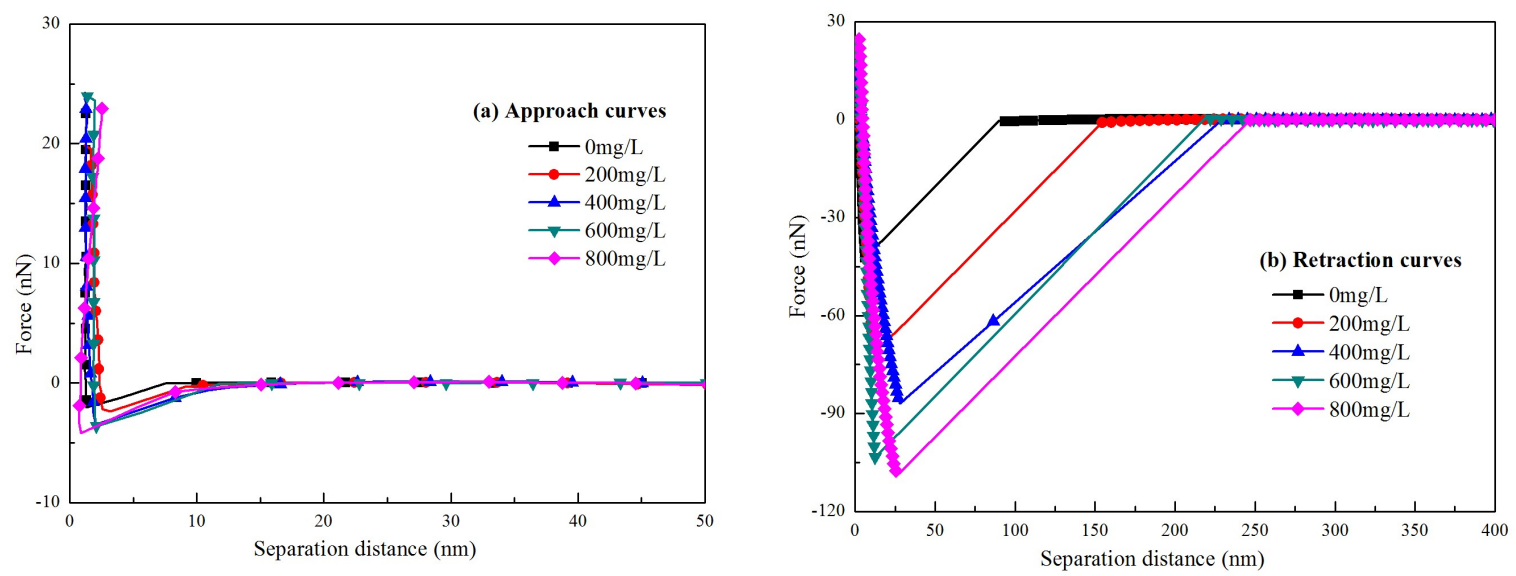

Figure 9. Interaction force between molybdenite surface and kaolinite particle in gypsum solution.

(a) Approach curves; (b) Retraction curves.

At all experimental conditions, there always have the short-range attractive force between the probe and the molybdenite face at distance less than $10 \mathrm{~nm}$ (Figure 9a). In deionized water, there is a little attractive force between kaolinite probe and molybdenite face in the process of approaching. Even though kaolinite and molybdenite are both negatively charge, the attractive force can be dominant by the Van Der Waals attraction at a short separation distance [33]. With the increase of gypsum solution concentration, the attractive force and the jump-in distance almost has no change.

When the probe is retracted away from the molybdenite face, the adhesion force is measured (Figure $9 b$ ). The quantification of adhesion force can provide a significant contribution on understanding and controlling of engineering separation process. The magnitude of adhesion force determines the stability of the particle adhesion to the surface. When gypsum solution concentration varies from 0 to $800 \mathrm{mg} / \mathrm{L}$, the adhesion force increases from $40 \mathrm{nN}$ to $108 \mathrm{nN}$, which indicates that the aggregates of molybdenite and kaolinite becomes more stable.

\section{Conclusions}

In this article, the interaction between kaolinite and molybdenite has been examined in a gypsum solution with different concentration using micro-flotation tests, zeta potential distribution measurements, SEM and AFM tests. The flotation recovery of molybdenite drops from $86 \%$ to $74 \%$ as the gypsum solution increases from 0 to $800 \mathrm{mg} / \mathrm{L}$. The inhibitory effect of gypsum on flotation may be caused by the slime coating performance of kaolinite on molybdenite surface through dissolved calcium ion of gypsum. Besides, through the measurements of zeta potential, it has proved the adsorption of dissolved calcium ion on minerals surface, as the mineral surface potential increase. Moreover, the combined molybdenite-kaolinite in gypsum solutions has the zeta potential between the two single minerals, illustrating that kaolinite coats on molybdenite surface, as observed in the SEM results. The AFM measurements show that the kaolinite particle and molybdenite surface show stronger adhesion force as the gypsum solution concentration increases, which indicates that the aggregates of molybdenite and kaolinite becomes more stable, so the flotation recovery of molybdenite decreases. The results show good agreement with zeta potential measurements and micro-flotation results.

Author Contributions: L.S. and Y.C. conceived and designed the experiments; L.S. performed the experiments, analyzed the data and wrote the paper; Y.L. and Z.M. helped in the preparation of the paper and in checking the drafts of the paper. 
Funding: This research was funded by National Nature Science Foundation of China (Grant Number 51574240), National Nature Science Foundation of China (Grant Number U1704252), the National Key Technology R\&D Program for the 12th five-year plan of China (Grant number 2014BAB01B05) and the Natural Science Foundation of Jiangsu Province (Grant number BK20150192).

Conflicts of Interest: The authors declare no conflict of interest.

\section{References}

1. Fleischauer, P.D.; Bauer, R. Chemical and structural effects on the lubrication properties of sputtered $\mathrm{MoS}_{2}$ films. Tribol. Trans. 1988, 31, 239-250. [CrossRef]

2. Tye, C.T.; Smith, K.J. Catalytic activity of exfoliated $\mathrm{MoS}_{2}$ in hydrodesulfurization, hydrodenitrogenation and hydrogenation reactions. Top. Catal. 2006, 37, 129-135. [CrossRef]

3. Karunadasa, H.I.; Chang, C.J. A molecular $\mathrm{MoS}_{2}$ edge site mimic for catalytic hydrogen generation. Science 2012, 335, 698-702. [CrossRef] [PubMed]

4. Ganatra, R.; Zhang, Q. Few-layer $\mathrm{MoS}_{2}$ : A promising layered semiconductor. ACS Nano 2014, 8, 4074-4099. [CrossRef] [PubMed]

5. Cheng, R.; Jiang, S.; Chen, Y.; Liu, Y.; Weiss, N.; Cheng, H.C.; Wu, H.; Huang, Y.; Duan, X. Few-layer molybdenum disulfide transistors and circuits for high-speed flexible electronics. Nat. Commun. 2014, 5, 5143. [CrossRef] [PubMed]

6. López-Valdivieso, A. The heterogeneity of the basal plane of molybdenite: Its effect on molybdenite floatability and calcium ion adsorption. In Proceedings of the 9th International Mineral Processing Conference, Santiago, Chile, 20-23 November 2012; pp. 21-23.

7. Yang, B.; Song, S.; López-Valdivieso, A. Effect of particle size on the contact angle of molybdenite powders. Miner. Process. Extr. Metall. Rev. 2014, 35, 208-215. [CrossRef]

8. Raghavan, S.; Hsu, L.L. Factors affecting the flotation recovery of molybdenite from porphyry copper ores. Int. J. Miner. Process. 2015, 12, 145-162. [CrossRef]

9. Liu, G.Y.; Zhong, H.; Xia, L.Y.; Wang, S.; Xu, Z.H. Improving copper flotation recovery from a refractory copper porphyry ore by using ethoxycarbonyl thiourea as a collector. Miner. Eng. 2011, 24, 817-824. [CrossRef]

10. Chander, S.; Fuerstenau, D.W. On the natural floatability of molybdenite. Trans. AIME 1972, 252, 62-69.

11. López-Valdivieso, A.; Madrid-Ortega, I.; Reyes-Bahena, J.L.; Sánchez-López, A.A.; Song, S. Propiedades de la interface molibdenita/solución acuosa y su relación con la flotabilidad del mineral. In Proceedings of the XVI Congreso International de Metalurgia Extractiva, Saltillo, Mexico, 26-28 April 2006; pp. 226-235.

12. Akdemir, Ü.; Sönmez, O. Investigation of coal and ash recovery and entrainment in flotation. Fuel Process. Technol. 2003, 82, 1-9. [CrossRef]

13. Basnayaka, L.; Subasinghe, N.; Albijanic, B. Influence of clays on the slurry rheology and flotation of a pyritic gold ore. Appl. Clay Sci. 2017, 136, 230-238. [CrossRef]

14. Cruz, N.; Peng, Y. Rheology measurements for flotation slurries with high clay contents-A critical review. Miner. Eng. 2016, 98, 137-150. [CrossRef]

15. Forbes, E.; Davey, K.J.; Smith, L. Decoupling rheology and slime coatings effect on the natural flotability of chalcopyrite in a clay-rich flotation pulp. Miner. Eng. 2014, 56, 136-144. [CrossRef]

16. Gupta, V.; Miller, J.D. Surface force measurements at the basal planes of ordered kaolinite particles. J. Colloid Interface Sci. 2010, 344, 362. [CrossRef] [PubMed]

17. Sun, W.; Ouyang, K.; Zhang, L.; Hu, Y.; Chen, C. Preparation of hydrolyzate of hogwash oil (HHO) and its application in separating diaspore from kaolinite. Miner. Eng. 2010, 23, 670-675. [CrossRef]

18. Xing, Y.; Gui, X.; Cao, Y. Effect of calcium ion on coal flotation in the presence of kaolinite clay. Energy. Fuel. 2016, 30, 1517-1523. [CrossRef]

19. Triffett, B.; Veloo, C.; Adair, B.J.I.; Bradshaw, D. An investigation of the factors affecting the recovery of molybdenite in the Kennecott Utah Copper bulk flotation circuit. Miner. Eng. 2008, 21, 832-840. [CrossRef]

20. Cruz, N.; Peng, Y.; Wightman, E.; Xu, N. The interaction of clay minerals with gypsum and its effects on copper-gold flotation. Miner. Eng. 2015, 77, 121-130. [CrossRef] 
21. Hirajima, T.; Suyantara, G.P.W.; Ichikawa, O.; Elmahdy, A.M.; Miki, H.; Sasaki, K. Effect of $\mathrm{Mg}^{2+}$ and Ca ${ }^{2+}$ as divalent seawater cations on the floatability of molybdenite and chalcopyrite. Miner. Eng. 2016, 96-97, 83-93. [CrossRef]

22. Wan, H.; Yang, W.; Cao, W.C.; He, T.S.; Liu, Y.Y.; Yang, J.B.; Guo, L.; Peng, Y.J. The interaction between Ca ${ }^{2+}$ and molybdenite edges and its effect on molybdenum flotation. Minerals 2017, 7, 141. [CrossRef]

23. Ikumapayi, F.; Makitalo, M.; Johansson, B.; Rao, K.H. Recycling of process water in sulphide flotation: Effect of calcium and sulphate ions on flotation of galena. Miner. Eng. 2012, 39, 77-88. [CrossRef]

24. Xu, Z.H.; Liu, J.J.; Choung, J.W.; Zhou, Z.A. Electrokinetic study of clay interactions with coal in flotation. Int. J. Miner. Process. 2003, 68, 183-196. [CrossRef]

25. Mitchell, T.K.; Nguyen, A.V.; Evans, G.M. Heterocoagulation of chalcopyrite and pyrite minerals in flotation separation. Adv. Colloid Interface Sci. 2005, 114-115, 227-237. [CrossRef] [PubMed]

26. Kusuma, A.M.; Liu, Q.; Zeng, H. Understanding interaction mechanisms between pentlandite and gangue minerals by zeta potential and surface force measurements. Miner. Eng. 2014, 69, 15-23. [CrossRef]

27. Liu, J.; Miller, J.D.; Yin, X.; Gupta, V.; Wang, X. Influence of ionic strength on the surface charge and interaction of layered silicate particles. J. Colloid Interface Sci. 2014, 432, 270-277. [CrossRef] [PubMed]

28. Lu, Z.; Liu, Q.; Xu, Z.; Zeng, H. Probing anisotropic surface properties of molybdenite by direct force measurements. Langmuir 2015, 31, 11409-11418. [CrossRef] [PubMed]

29. Drelich, J.; Jang, W.H.; Miller, J.D. Examination of adsorbed oleate layers at a fluorite surface by contact angle measurements and FT-IR/IRS spectroscopy. Langmuir 1997, 13, 1345-1351. [CrossRef]

30. Fa, K.; Nguyen, A.V.; Miller, J.D. Interaction of calcium dioleate collector colloids with calcite and fluorite surfaces as revealed by AFM force measurements and molecular dynamics simulation. Int. J. Miner. Process. 2006, 81, 166-177. [CrossRef]

31. Bremmell, K.E.; Fornasiero, D.; Ralston, J. Pentlandite-Lizardite interactions and implications for their separation by flotation. Colloid Surf. A 2005, 252, 207-212. [CrossRef]

32. Sun, L.; Liu, J.; Liao, Y. Implication and collecting mechanism of emulsified sodium vegetable oleate on fluorite flotation. Physicochem. Probl. Miner. Process. 2018, 54, 211-219. [CrossRef]

33. Xie, L.; Wang, J.; Yuan, D.; Shi, C.; Cui, X.; Zhang, H.; Liu, Q.; Liu, Q.X.; Zeng, H.B. Interaction mechanisms between air bubble and molybdenite surface: Impact of solution salinity and polymer adsorption. Langmuir 2017, 33, 2353-2361. [CrossRef] [PubMed]

34. Oats, W.J.; Ozdemir, O.; Nguyen, A.V. Effect of mechanical and chemical clay removals by hydrocyclone and dispersants on coal flotation. Miner. Eng. 2010, 23, 413-419. [CrossRef]

35. Uribe, L.; Gutierrez, L.; Jerez, O. The depressing effect of clay minerals on the floatability of chalcopyrite. Miner. Process Extr. Metall. Rev. 2016, 37, 227-235. [CrossRef]

36. Wan, H.; Yang, W.; He, T.; Yang, J.; Guo, L.; Peng, Y. The influence of $\mathrm{Ca}^{2+}$ and $\mathrm{pH}$ on the interaction between PAHs and molybdenite edges. Minerals 2017, 7, 104. [CrossRef]

37. Yukselen-Aksoy, Y.; Kaya, A. A study of factors affecting on the zeta potential of kaolinite and quartz powder. Environ. Earth Sci. 2011, 62, 697-705. [CrossRef]

38. Alkan, M.; Demirbas, O.; Dogan, M. Electrokinetic properties of kaolinite in mono- and multivalent electrolyte solutions. Microporous Mesoporous Mater. 2005, 83, 51-59. [CrossRef]

39. Bowen, W.R.; Hilal, N.; Lovitt, R.W.; Wright, C.J. An atomic force microscopy study of the adhesion of a silica sphere to a silica surface-effects of surface cleaning. Colloid Surf. A 1999, 157, 117-125. [CrossRef]

40. Brant, J.A.; Childress, A.E. Membrane-colloid interactions: Comparison of extended DLVO predictions with AFM force measurements. Environ. Eng. Sci. 2002, 19, 413-427. [CrossRef]

41. Kostakis, T.; Ettelaie, R.; Murray, B.S. Effect of high salt concentrations on the stabilization of bubbles by silica particles. Langmuir 2006, 22, 1273. [CrossRef] [PubMed]

(C) 2018 by the authors. Licensee MDPI, Basel, Switzerland. This article is an open access article distributed under the terms and conditions of the Creative Commons Attribution (CC BY) license (http://creativecommons.org/licenses/by/4.0/). 